\title{
Middle Ear Implant for Sensorineural and Conductive Hearing Loss: Indications and Audiological Results
}

\author{
Yeonjoo Choi ${ }^{\mathbb{D}}$, Yehree Kim, Taeuk Cheon, and Hong Ju Park (iD \\ Seoul, Korea \\ 감각신경성 난청 및 전음성 난청에서 인공중이의 적응증 및 청력 결과 \\ 최연주 · 김예리 · 천태욱 · 박홍주 \\ 울산대학교 의과대학 서울아산병원 이비인후과학교실
}

Department of Otorhinolaryngology-Head and Neck Surgery, Asan Medical Center, University of Ulsan College of Medicine,

Received July 2, 2020

Revised September 18, 2020

Accepted September 28, 2020

Address for correspondence

Hong Ju Park, MD, PhD

Department of Otorhinolaryngology-

Head and Neck Surgery,

Asan Medical Center,

University of Ulsan

College of Medicine,

88 Olympic-ro 43-gil, Songpa-gu,

Seoul 05505 , Korea

Tel $+82-2-3010-3700$

Fax $+82-2-489-2773$

E-mail dzness@amc.seoul.kr
Background and Objectives Middle ear implants (MEI) have been reported to be an effective and safe alternative for the treatment of sensorineural hearing loss (SNHL) and conductive hearing loss (CHL). This study aimed to compare the functional outcomes between SNHL and CHL in terms of audiological gains.

Subjects and Method The medical records of 14 consecutive SNHL and CHL patients who underwent MEI surgeries from 2015 to 2019 by a single surgeon were retrospectively reviewed. Audiological changes using hearing aids (HA) and MEI were compared.

Results In SNHL, the mean unaided air-conduction pure tone audiometry (PTA), (57.7 dB HL) decreased significantly using HA and MEI (44.7 and $41.4 \mathrm{~dB}$ HL), but with no significant difference from each other. Unaided word recognition score (WRS) at $65 \mathrm{~dB}$ HL (45.1\%) was significantly improved using HA and MEI (72.6\% and 76.6\%), with no significant difference. In CHL, the mean unaided air-conduction and bone-conduction PTA were 77.1 (57.5-93.8) and 44.1 (26.3-57.5) dB HL. Three patients could not use conventional HAs due to otorrhea and deformity of the external auditory canal by previous surgeries and 4 patients had used conventional HAs before MEI. Though both HA and vibrant soundbridge (VSB) showed improvement of hearing thresholds (32.0 and $48.8 \mathrm{~dB} \mathrm{HL})$ and WRS $(80.0 \%$ and $94.9 \%)$, it was significant only when using VSB. There was no significant difference between HA and VSB. Conclusion MEI can be an effective treatment option for both SNHL and CHL patients, especially for those who suffered from problems using conventional HA.

Korean J Otorhinolaryngol-Head Neck Surg 2021;64(6):391-8

Key Words Conductive hearing loss · Middle ear implant - Sensorineural hearing loss.

\section{서 론}

인공중이(middle ear implant)는 내이 구조인 이소골이나 정원창을 통해 와우를 직접적으로 진동으로 자극하여 소리 의 전도를 증폭시키는 장치이다. ${ }^{1)}$ 현재 우리나라 국민건강보

This is an Open Access article distributed under the terms of the Creative Commons Attribution Non-Commercial License (https://creativecommons.org/licenses/by-nc/4.0) which permits unrestricted non-commercial use, distribution, and reproduction in any medium, provided the original work is properly cited.
험 기준에 따르면, 인공중이의 건강보험 기준은, 만 18 세 이상 의 양측 비진행성 감각신경성 난청 환자로 편측 순음청력이 $41 \sim 70 \mathrm{~dB}(500,1000,2000,3000$ (혹은 4000) Hz 평균치)인 경우, 어음명료도가 $50 \%$ 이상인 경우, 최소한 1개월 이상 적 절한 보청기 착용에도 청각재활의 효과가 제한적이거나 지속 적인 보청기 착용이 어려운 경우에 해당한다. ${ }^{2)}$ 따라서, 국내 에서는 인공중이는 기존의 보청기 사용에 불편함을 겪는 감 각신경성 난청(sensorineural hearing loss) 환자들 대상으로 
많이 시행되고 있다.

인공중이는 수술을 통하여 vibrating ossicular prosthesis (VORP)를 측두골 내에 위치시키게 되고, 어음처리장치(speech processor)는 외부 장치로서 외부 소리를 처리하여 전기신호 로 변환시켜 VORP로 전달하게 된다. VORP는 외부 장치로 부터 소리를 받아들이게 되는 부분이 이개 뒤쪽에 고정되게 되며, 와우를 자극하는 floating mass transducer(FMT)로 이루어진다. 진동하는 $\mathrm{FMT}$ 는 환자의 중이강 내의 상태에 따라 위치시키는 방법이 다르다. 감각신경성 난청 환자의 경 우, 중이강 내 해부학적 이상이 없는 경우가 많아 FMT는 침 골(incus)의 장돌기(long process) 혹은 단돌기(short process) 에 위치시키게 된다(incus vibroplasty). 전음성 난청(conductive hearing loss) 혹은 혼합성 난청(mixed hearing loss) 환 자들의 경우, 기존의 보청기 사용으로는 청력 개선의 효과가 크지 않고, 이소골 결손과 같은 중이강 내 해부학적인 변화가 있는 경우가 많아 난원창(oval window) 혹은 정원창(round window)에 직접 위치시키거나, 혹은 등골(stapes)의 두부 (head) 등 다양한 위치에 고정된다(round window, oval window, stapes vibroplasty).,4)

일반적으로 인공중이의 장점으로는 일반 보청기와 다르게 외이도를 막지 않는 점, 소리의 자연스러움, 피드백이나 $\mathrm{Oc}^{-}$ clusion effect가 발생하지 않는 점, 소음하에서 언어이해도의 증가, 일반 보청기에 비해 상대적으로 잘 보이지 않아서 유리 한 점 등이 있어 전 세계적으로 많이 사용된다. ${ }^{1)}$ 우리나라는 인공중이 보험 기준으로 인하여 대부분의 경우가 감각신경 성 난청 환자들을 대상으로 수술이 시행되었으나, 국외 연구 에 의하면 감각신경성 난청 환자들에 있어서 청력 개선 자체 에서는 기존의 보청기에 비하여 인공중이의 청력 개선 효과 가 크게 차이가 없다는 보고가 있으며, ${ }^{5)}$ 전음성 혹은 혼합성 난청 환자들을 대상으로 시행한 인공중이에서 보청기에 비교 하여 청력 개선이 보다 효과적임이 보고되고 있다..$^{6-8)}$

따라서, 본 연구에서는 감각신경성, 전음성 및 혼합성 난청 환자들을 대상으로 인공중이의 청력 개선 효과에 대해 알아 보고자 하였으며, 이와 함께 이 시술이 활발하게 사용되고 있는 외국에서의 결과를 분석하여 국내에서의 적절한 적응 증에 대해 논의해 보고자 한다.

\section{대상 및 방법}

\section{연구 설계}

이 연구는 2015 2019년까지 연구가 이루어진 본원에서 일 인술자에 의해 인공중이 수술을 시행 받은 환자들을 대상으 로 후향적으로 시행되었다. 본 연구에서의 감각신경성 난청
군의 인공중이 이식의 적응증은 국민건강보험에서 제시하는 급여기준에 부합하는 환자들을 대상으로 하였다. 연구에 포 함된 7명의 만성 중이염을 진단받은 전음성 난청 환자 중 5명 의 환자들은 이전 유양돌기삭개술 및 이소골성형술을 시행 하였음에도 청력 호전이 없고 추가적인 이소골성형술에도 청력 개선을 기대할 수 없는 환자들이었고, 2 명의 환자들의 경우 인공중이 수술과 함께 유양돌기삭개술 및 고실성형술을 시행하였다. 두명 모두 양쪽 중이염 환자로, 한 환자의 경우 양쪽 이관기능장애와 반대쪽 중이염으로 재수술에도 불구 하고 여전히 전음성 난청이 해결되지 않는 환자로, 수술 후 보청기 사용과 인공중이 수술 방법 중 인공중이 수술을 선 택하였으며, 수술 시 고막유착의 가능성이 높아 이소골성형 술이 고려되지 않았다. 두번째 환자도 수술 후 보청기와 인 공중이 중 두가지 방법에서 수술을 선택한 환자로, 반대쪽은 보청기를 사용하고 있으나 만족감이 높지 않아 고막천공을 복구하는 제 1 형 고실성형술과 동시에 인공중이 수술을 시행 하였다. 두 군을 대상으로 하여 인공중이 시행 후 청력의 변 화에 대해 알아보고 하였다.

이 연구의 프로토콜은 본 연구기관의 생명윤리위원회(Institutional Review Board, IRB)에서 승인받았다(2020-0968).

\section{수술적 방법}

귀뒤접근법(postauricular approach)을 통해 단순유양돌기 삭개술(simple mastoidectomy)를 시행한 뒤 노출 정도에 따 라 필요 시 추가로 후고실개방술(posterior tympanotomy)을 시행한다. 환측의 측두골(temporal bone)에 VORP를 삽입할 우물(wall)을 만들고, 외부 장치로부터 소리를 받는 VORP 부분을 삽입하고 고정한다.

감각신경성 난청 환자의 경우 모든 이소골들이 정상으로, VORP의 끝부분인 FMT는 침골의 장돌기 혹은 단돌기에 위 치시키게 되는데, 본 연구에서는 7예 모두 침골의 단돌기에 FMT를 위치시켰다.

전음성 난청 환자들의 경우 개방성 유양돌기절제술을 이미 시행한 환자에서는 고막에 직접적인 접촉이 되는 $\mathrm{FMT}$ 의 노 출을 피하기 위해 연골편으로 보강을 하였으며, 전선(wire)의 노출을 피하기 위해 전선이 지나갈 유양돌기의 적절한 위치에 드릴로 고랑(furrow)을 만들어 전선을 위치시켰고, 피부로의 직접적인 노출을 최소화하기 위해 그 위에 골절편을 덮고, 연 골편을 이용하여 추가적으로 보강하였다. 본 연구에서는 7예 의 전음성 난청 환자 중 6예에서는 정원창에 직접 위치시켰 고, 1 예에서는 침골의 장돌기에 위치시켰다.

이후 절개부위를 봉합하고 수술을 종료되었고, VORP가 측두골에 삽입된 부위의 부종을 예방하기 위하여 2일간 압 
박드레싱을 시행하였다.

\section{변수들}

환자들의 나이, 성별, 병변의 방향, 수술 전 고막의 상태, 이전 기존 보청기 사용 유무, 추적 관찰 기간에 대하여 조사 하였다. 청력의 변화의 경우, 환자들이 기존의 사용하던 보청 기를 착용하였을 때와 인공중이 수술을 시행하였을 때를 비 교하여, 향상되는 청력의 변화에 대하여 순음청력검사(pure tone audiometry)와 어음청력검사(speech audiometry)를 이용하였다.

\section{청력의 측정}

청력의 측정 인공중이 수술 전, 수술 시행 후 마지막 외래 방문 시 시행한 순음청력검사를 이용하였으며, 500, 1000, $2000,4000 \mathrm{~Hz}$ 에서의 역치값을 평균 내어 4분법(four-frequency average, 4FA)을 사용하였다. 또한, 단어인지도 검사 (word recognition score, WRS)는 $65 \mathrm{~dB}$ HL의 소리 자극 을 이용하여 보청기를 사용하지 않은 상태와 보청기를 사용 한 상태[hearing aid(HA)-aided WRS)], 그리고 인공중이를 사용한 상태[vibrant soundbridge(VSB)-aided WRS]에서 각각 검사하였다. 모든 환자들은 인공중이 수술 전 순음청력 검사 및 어음청력검사를 시행하였으며, 인공중이 수술 전 보 청기 착용 기왕력이 있는 환자들에 대해서는 보청기를 착용 한 상태에서 기능이득(functional gain, $\mathrm{FG}$ )을 추가로 측정 하였다. 보청기를 사용한 상태(HA-aided WRS), 그리고 인 공중이를 사용한 상태(VSB-aided WRS)에서의 단어인지도 검사는 청각보조기를 착용한 상태에서 $65 \mathrm{~dB} \mathrm{HL}$ 의 소리 자 극에서의 단어인지도검사를 시행하여 일상생활 중의 단어인 지도를 평가하였다.

모든 감각신경성 난청 환자들은 수술 전 1년 이상 기존의 보청기를 사용하였고, 전음성 난청 환자들의 경우에는 7명중 4 명에서 수술 전 1년 이상 보청기를 사용하였으며, 3 명은 보 청기 착용시 발생하는 이루와 수술로 인한 외이도 변형으로 피드백으로 인해 충분한 이득을 줄 수 없어 보청기를 사용할 수 없었다. 인공중이 수술 1년 뒤 인공중이를 착용한 상태에 서의 기능이득을 측정하여, 수술 전 기존 보청기를 사용하였 을 때와 비교하여 4 분법 순음청력역치와 단어인지도의 차이 를 비교하였다.

\section{통계 분석}

연속변수들은 평균값과 표준편차 혹은 중간값과 범위로 표 현되었고, 범주형 변수들은 수와 백분율로 표현된다. 변수들 은 Mann Whitney U test, Wilcoxon signed rank test, chi- squared test 혹은 Fisher's exact test를 통하여 비교하였다. $p$-value가 0.05보다 작은 경우를 통계학적으로 의미 있는 것 으로 보았다. 통계 분석은 IBM SPSS software, version 24.0 (IBM Corp., Armonk, NY, USA)를 이용하였다.

\section{결 과}

총 14 명의 환자, 감각신경성 난청 환자 7 명과 이전 만성중 이염으로 진단받은 전음성 난청 환자 7명이 포함되었다. 11명 의 남성, 3 명의 여성 환자 중 34 77세 사이의 환자들이 연구 에 포함되어 분석되었으며, 평균 추적 관찰 기간은 18.01 개월 이었다. 환자들의 특성은 Table 1에 설명되어 있다. 나이, 성 별, 방향 모두 감각신경성 난청군과 전음성 난청군 사이에 유 의미한 차이는 없었다.

최초의 고막상태의 경우 감각신경성 난청 환자들에 있어 서는 모두 정상을 보였으나, 전음성 난청군에서는 정상 4예 (57.1\%), 천공 2예(28.6\%), 육아형성 1예(14.3\%)가 확인되었다. 2예의 천공 증례의 경우 인공중이수술과 함께 유양돌기삭새 술 및 고실성형술을 함께 시행하였으며, 1 예의 육아형성 증 례의 경우, 인공중이 수술과 함께 육아종 제거술을 함께 시 행하였다.

기존 보청기 사용 여부를 보아도 감각신경성 난청 환자들 은 모두 1년 이상 보청기 사용력이 있으나, 전음성 난청 환자 들의 경우 4 명 $(57.1 \%)$ 환자들만 보청기 사용력이 확인되었다. 보청기 사용력이 확인되지 않은 3 명의 환자들의 경우 이전 보청기 사용력이 있으나, 잦은 이루와 기존의 수술로 인한 외 이도의 변형으로 충분한 증폭이 불가능하여 보청기 사용을 하지 않은 상태였다.

감각신경성 난청 환자들의 경우 수술 전 기도 순음청력검사

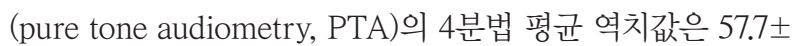
$8.6 \mathrm{~dB}$ HL로 그 범위는 45.0 68.8 dB HL이었다. 전음성 난 청 환자들의 대상으로 수술 전 기도 순음청력검사(PTA)를 시행하였을 때, 4분법 평균 역치값은 $77.1 \pm 14.0 \mathrm{~dB} \mathrm{HL}$ 로 그 범위는 57.5 93.8 dB HL이다. 수술 전 골도 순음청력검사 (PTA)에서의 4분법 역치값은 $44.1 \pm 12.0 \mathrm{~dB}$ HL로 그 범위 는 26.3 57.5 dB HL로, 기도골도역치차(air-bone gap)은 $33.0 \pm 6.6 \mathrm{~dB}$ 였다. 두 군 간의 기도 청력역치값을 비교해 보 았을 때에 유의하게 전음성 난청 환자들의 청력역치값이 높 게 나타났다 $(p=0.008)$.

Fig. $1 \mathrm{~A}$ 는 감각신경성 난청 환자들에서 주파수별( $0.5,1$, 2, $4 \mathrm{kHz}$ ) 및 4분법 수술 전 기도 순음청력(PTA)역치, 기존 의 보청기 착용 시 측정한 순음청력역치, 인공중이수술 후 측정한 순음청력역치에 대한 그래프이다 $(\mathrm{n}=7)$. 감각신경성 
Table 1. Patients characteristics

\begin{tabular}{|c|c|c|c|c|}
\hline Variable & SNHL $(n=7)$ & $\mathrm{CHL}(n=7)$ & Total $(n=14)$ & p value \\
\hline $\operatorname{Age}(y)$, mean (SD) & $57.43(11.09)$ & $57.57(13.35)$ & $57.50(11.79)$ & 0.983 \\
\hline Sex & & & & 0.192 \\
\hline Male & $7(100)$ & $4(57.1)$ & $11(78.6)$ & \\
\hline Female & 0 & $3(42.9)$ & $3(21.4)$ & \\
\hline Side & & & & 1.000 \\
\hline Left & $3(42.9)$ & $4(57.1)$ & $7(50.0)$ & \\
\hline Right & $4(57.1)$ & $3(42.9)$ & $7(50.0)$ & \\
\hline \multicolumn{2}{|c|}{ Preoperative tympanic membrane status } & & & 0.083 \\
\hline Intact & $7(100)$ & $4(57.1)$ & $11(78.6)$ & \\
\hline Perforation & 0 & $2(28.6)$ & $2(14.3)$ & \\
\hline Granulation & 0 & $1(14.3)$ & $1(7.1)$ & \\
\hline Conventional HA usage & $7(100)$ & $4(57.1)$ & $11(78.6)$ & 0.192 \\
\hline Follow up (m), mean (SD) & $17.90(12.87)$ & 18.09 (23.39) & $18.01(18.14)$ & 0.985 \\
\hline preoperative PTA (4FA) (dB HL) (SD) & $57.68(8.55)$ & $77.14(13.95)$ & $67.41(15.02)$ & 0.008 \\
\hline
\end{tabular}

Variables are expressed as number (percentage) unless indicated otherwise. SNHL: sensorineural hearing loss, $\mathrm{CHL}$ : conductive hearing loss, SD: standard deviation, HA: hearing aid, PTA: pure tone audiometry, 4FA: four-frequency average

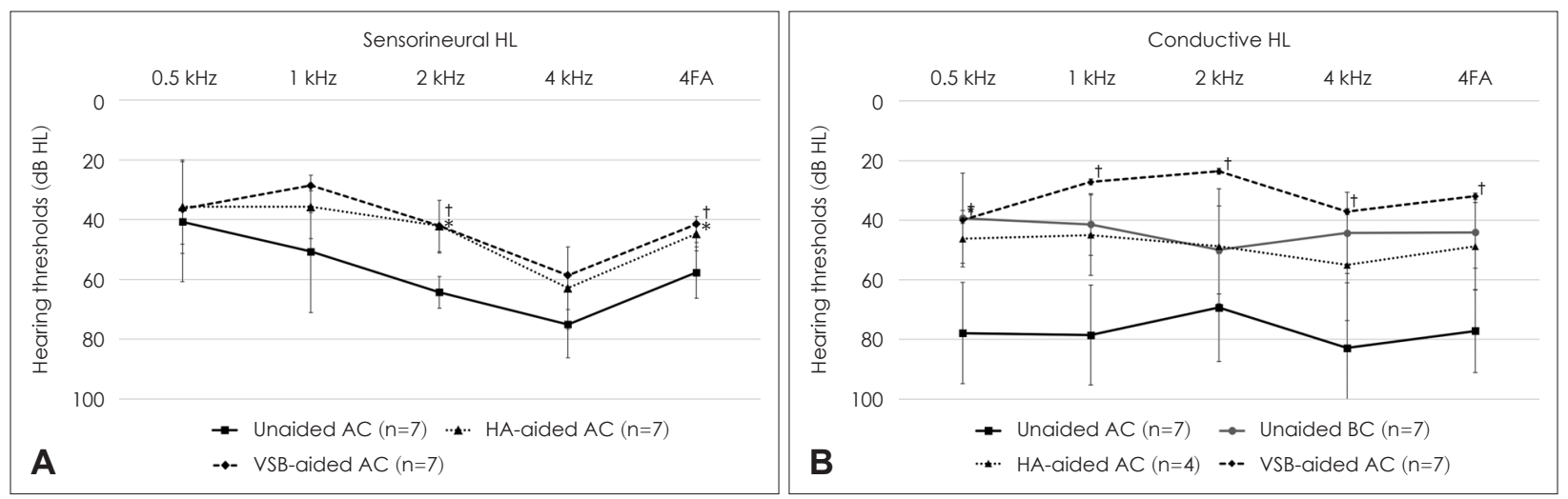

Fig. 1. Unaided and aided (HA and VSB) pure-tone thresholds at each frequency in the ears with sensorineural hearing loss (A) and conductive hearing loss (B). * $p<0.05$, comparison btw. unaided vs. HA-aided, Wilcoxon signed rank test, $t p<0.05$, comparison btw. unaided vs. VSB-aided, Wilcoxon signed rank test. HL: hearing loss, 4FA: four-frequency average, HA: hearing aid, VSB: vibrant soundbridge, $\mathrm{AC}$ : air conduction, $\mathrm{BC}$ : bone conduction.

난청 환자의 경우, 보청기 착용 시 4분법 역치는 $44.7 \pm 5.7 \mathrm{~dB}$ $\mathrm{HL}$, 인공중이 수술 후에는 $41.4 \pm 6.3 \mathrm{~dB}$ HL로 청력재활을 하지 않은(unaided) 청력역치(57.7 dB HL)에 비교하여 의미 있는 호전을 보였으나(보청기, $p=0.018$; 인공중이, $p=0.018$ ), 두 군간의 차이는 없었다 $(p=0.175)$. 각 주파수별로 비교할 경 우, $2 \mathrm{kHz}$ 에서는 청력재활을 하지 않은 상태(unaided)의 청력 역치와 비교하여 보청기 착용(HA-aided) 역치와 인공중이 수술 후(VSB-aided) 역치는 의미있게 감소하였으나(보청기, $p=0.016$; 인공중이, $p=0.017$ ), 다른 주파수에서 두 군 간에 청 력역치가 호전되는 차이는 없었다 $(p=0.242,0.916,0.054,0.752$ at $0.5,1,2,4 \mathrm{kHz}$ ).

Fig. $1 \mathrm{~B}$ 는 전음성 난청 환자들에서 주파수별 및 4 분법 수 술 전 기도 및 골도 순음청력역치 $(\mathrm{n}=7)$, 기존의 보청기 착용 시 측정한(HA-aided) 순음청력역치 $(n=4)$, 인공중이 수술 후
측정한(VSB-aided) 순음청력역치 $(\mathrm{n}=7)$ 에 대한 그래프이다. 전음성난청 환자에서 보청기 착용 역치는 $48.8 \pm 14.7 \mathrm{~dB} \mathrm{HL}$ 로 청력재활을 하지 않은(unaided) 청력역치(77.1 $\pm 14.0 \mathrm{~dB}$ $\mathrm{HL})$ 에 비교하여 통계학적으로 의미있는 호전을 보이지 않았 으나 $(p=0.066)$ 호전되는 경향을 보였고, 인공중이 수술 후에 는 $32.0 \pm 4.5 \mathrm{~dB}$ HL로 통계학적으로 의미있는 호전을 보였으 며 $(p=0.018)$, 두 군 간의 차이는 없었다 $(p=0.273)$. 각 주파수 별로 비교할 경우, 모두 주파수에서 청력재활을 하지 않은 상 태(unaided)의 청력역치와 비교하여 보청기 착용(HA-aided) 역치는 감소하는 경향을 보였으나 통계적으로 유의하지 않았 으며 $(p=0.066,0.068,0.066,0.066)$, 인공중이 수술 후(VSBaided) 역치는 모든 주파수에서 의미있게 감소하였으며 $(p=$ $0.017,0.018,0.017,0.027$ at $0.5,1,2,4 \mathrm{kHz})$, 두 군 간의 차 이는 없었다 $(p=0.593,0.066,0.144,0.581$ at $0.5,1,2,4 \mathrm{kHz})$. 
Fig. 2는 보청기 착용 전 $65 \mathrm{~dB} \mathrm{HL}$ 의 소리자극에서의 일 음절 단어인지도(WRS), 보청기 착용 시와 인공중이 착용 시 $65 \mathrm{~dB}$ HL의 소리자극에서의 단어인지도를 비교한 그래프이 다. 감각신경성 난청 환자의 경우, 청각재활을 하지 않은 경 우(unaided) 단어인지도는 $45.1 \pm 28.6 \%$ 로 보청기 착용 시 단 어인지도는 $72.6 \pm 22.2 \%$, 인공중이 수술 후 $76.6 \pm 13.4 \%$ 로 통계적으로 의미있게 향상되었고(보청기, $p=0.028$; 인공중이,

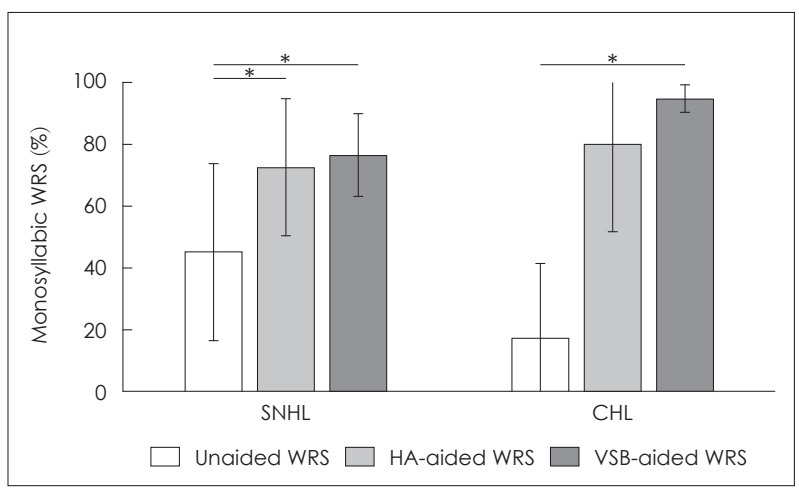

Fig. 2. Unaided and aided (HA and VSB) monosyllabic WRS at the sound stimulation of $65 \mathrm{~dB} H \mathrm{HL}$ in the ears with $\mathrm{SNHL}$ and $\mathrm{CHL}$. ${ }^{*} p<0.05$, Wilcoxon signed rank test. WRS: word recognition score, $\mathrm{SNHL}$ : sensorineural hearing loss, $\mathrm{CHL}$ : conductive hearing loss, HA: hearing aid, VSB: vibrant soundbridge. $p=0.018)$, 두 군 간에는 통계적으로 차이는 없었다 $(p=0.553)$. 전음성 난청 환자의 경우, 청각재활을 하지 않은 경우(unaided) 단어인지도는 $17.1 \pm 24.3 \%$ 로 보청기 착용 시 단어인지도 (WRS)는 $80.0 \pm 28.3 \%$ 로 증가하였으나 통계적으로 의미있게

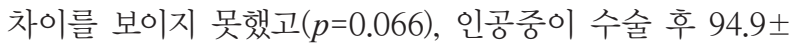
$4.5 \%$ 로 통계적으로 의미있게 향상되었으며 $(p=0.018)$, 두 군 간에는 통계적으로 유의성은 입증되지 못했다 $(p=0.285)$.

Fig. 3은 연구에 포함된 감각신경성 난청 및 전음성 난청 환자들 개개인의 인공중이 수술 전후로의 청력 변화를 기도 순음역치 및 일음절단어인지도로 나타내는 그래프이다.

\section{고 찰}

이 연구는 감각신경성 난청 및 전음성 난청 환자를 대상으 로 인공중이를 시행하였을 경우의 청력 개선 정도에 대하여 알아보고자 하였다. 본 연구의 결과, 감각신경청 난청 환자에 서 보청기 및 인공중이를 사용한 경우의 청력역치는 보청기를 사용하지 않은 상태(unaided)의 청력역치와 비교해 보았을 때 의미있게 청력 개선을 얻을 수 있음을 보여주었으나, 보청 기와 인공중이 두 군 간에 통계적으로 유의한 차이를 보이지
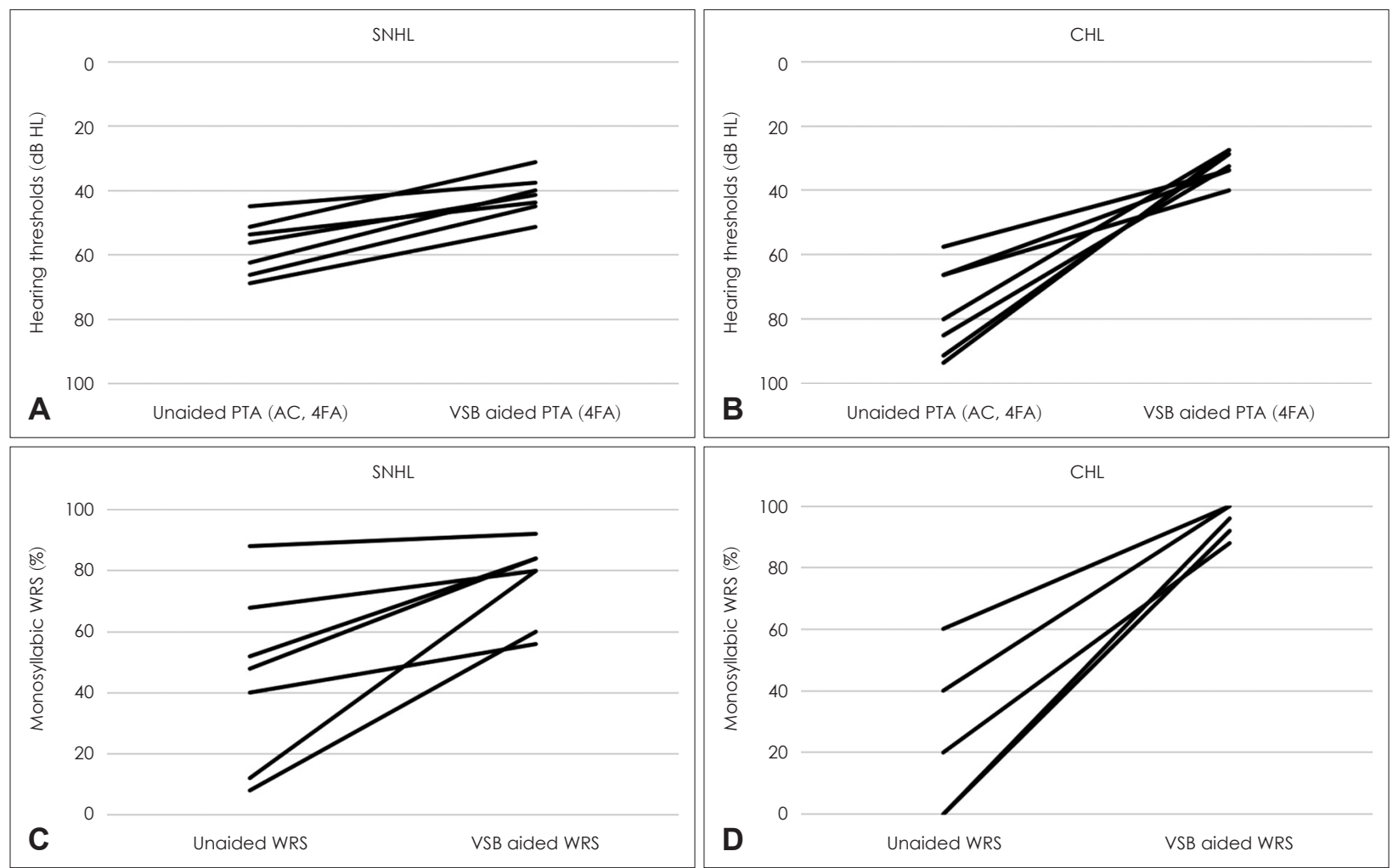

Fig. 3. Unaided and VSB-aided pure-tone threshold with each patients of SNHL (A) and CHL (B). Unaided and VSB-aided monosyllabic WRS at the sound stimulation of $65 \mathrm{~dB} H L$ with each patients of $S N H L(C)$ and $\mathrm{CHL}(\mathrm{D})$. SNHL: sensorineural hearing loss, $\mathrm{CHL}$ : conductive hearing loss, PTA: pure tone audiometry, AC: air-conduction, 4FA: four-frequency average, VSB: vibrant soundbridge, WRS: word recognition score. 
않았고, $65 \mathrm{~dB}$ HL에서의 단어인지도도 보청기와 인공중이 를 통해 단어인지도의 호전을 보여주었으나 두 군 간에는 큰 차이를 보이지 않았다.

감각신경성 난청 환자들에 있어서는 인공중이를 통해 얻는 청력학적 이득이 기존의 보청기에 비해 크게 차이를 보이지 않음을 보고한 기존 연구가 있다. Verhaegen 등'의 연구는 인공중이와 기존의 보청기 사이에서 청력적 차이는 없으며, 청력 저하가 심하지 않다면 감각신경성 난청 환자에서 잦은 외이도염이 생기는 경우 인공중이가 좋은 치료적 선택이 될 수 있다고 보고한다. 하지만 감각신경성 난청 환자에서 기존 보청기에 비해 인공중이를 시행하였을 경우, 잔존 청력에는 변화가 없었으나 환자의 만족도와 수행능력이 향상된다는 보 고가 있고, ${ }^{10)}$ 기존의 보청기를 사용하는 것에 비해 인공중이 를 시행하였을 경우, 언어 인식능력에는 큰 차이가 없으나 기 능 이득(FG)과 환자의 삶의 질 향상에 더 우위에 있다는 보 고도 있다. ${ }^{11,12)}$ 따라서, 감각신경성 난청 환자들이 인공중이를 선택함에 있어서 국내의 건강보험 기준에 포함되어 있는 조 건인 기존 보청기의 청력학적 한계를 극복하기 위해 사용되 기보다는, 기존의 보청기 사용으로 인해 발생하는 외이도염, 통증 등과 같은 불편감과 부작용을 해소하고, 소리의 부자연 스러움을 극복하고 외형적 이득을 얻기 위한 대체 방안으로 생각하는 것이 적절할 것으로 생각된다. ${ }^{1,13}$

감각신경성 난청 환자에서 인공중이를 통한 이득과 기존의 보청기를 사용한 이득이 비슷한 이유로는 두 기기의 최대 출 력의 차이로 생각해 볼 수 있다. 기존 사용되는 보청기의 최대 출력이 $130 \mathrm{~dB} \mathrm{HL}$ 이상인 것에 반해 인공중이의 최대 출력은 약 $85 \mathrm{~dB} \mathrm{HL}$ 로 상대적으로 낮다는 점을 들 수 있다. ${ }^{14)}$ 이는 일반적인 보청기는 크게 자극된 소리에 대한 환자의 과민성, 피드백이나 외이도 폐쇄효과 등 다양한 원인에 의해 과도한 정도로 소리의 증폭을 주지 않은 것이지 출력이 부족하여 높 은 증폭을 주지 못한 것이 아니기 때문으로 생각된다. 반면, 인공중이의 최대 출력은 약 $85 \mathrm{~dB} \mathrm{HL}$ 로 근본적으로 일반 보청기보다 최대 출력이 낮을 수밖에 없다. 따라서, 수술 전 감각신경성 난청의 역치가 너무 높을 경우에는 인공중이로는 충분한 이득을 줄 수 없게 되어 이 경우 일반적인 보청기가 더 도움이 될 수 있다는 점을 알아야 하겠다. 본 연구에서 몇 몇 환자에서 추가적인 이득을 주고자 하였으나 최대 출력의 부족으로 충분한 이득을 줄 수 없는 경우가 있었다. 현재 우 리나라의 경우, 감각신경성 난청의 청력역치가 40 70 dB HL 인 경우를 인공중이의 적응증으로 하고 있으며, 제조 회사에 서는 감각신경성 난청의 경우 청력역치가 $75 \mathrm{~dB} \mathrm{HL}$ 이내일 경우, 전음성 난청의 경우 골도 청력역치가 $55 \mathrm{~dB} \mathrm{HL}$ 이내일 경우를 적응증으로 제시하고 있다. ${ }^{15)}$ 그러나, 인공중이의 최
대 출력은 약 $85 \mathrm{~dB}$ HL이며 일반적으로 $35 \mathrm{~dB}$ 의 dynamic range가 필요한 것으로 고려하면, 약 $50 \mathrm{~dB} \mathrm{HL}$ 이내의 청력 역치를 적절한 중이이식의 적응증으로 보고하고 있으며, ${ }^{14)}$ 감 각신경성 난청의 경우 청력역치가 $70 \mathrm{~dB} \mathrm{HL}$ 인 환자에서는 장기적인 청력재활효과를 기대하기 어려울 수 있음을 알 수 있다. 따라서, 감각신경성 난청의 경우 일반 보청기를 통해서 인공중이보다 더 큰 소리의 증폭이 가능하기 때문에 난청의 정도가 심한 중고도의 감각신경성 난청 환자에서 인공중이의 선택에 있어서 신중할 필요가 있어 보인다. ${ }^{9,16)}$ 그러나, 정원창 을 통하여 VSB 자극을 할 경우에는 커플러를 사용하면 보 다 강력한 자극이 가능하여, 보다 심한 난청에도 인공중이를 사용할 수 있다는 보고도 있어, 인공중이 적응증의 기준이 아직 정확히 확립되지는 않은 실정이다.1,13)

본 연구에서 감각신경청난청 환자에서 청력역치의 호전 정 도를 주파수별로 분석하였을 때에도 고주파수에서는 인공중 이를 사용한 청력역치는 보청기를 사용한 청력역치와 비교해 보았을 때 상대적으로 더 낮은 역치를 보여 청력개선의 호전 이 더 큰 경향을 보였으나 통계적으로 유의한 차이를 보이지 는 않았다. 기존의 연구에서는 인공중이는 주파수 특이적 소 리의 증폭을 하는 것으로 보고되며, 저주파수에서의 출력이 낮은 특징을 보이는 것으로 보고된다. ${ }^{17)}$ 감각신경성 난청 환자 에서 고주파수에서의 인공중이의 이득은 일반적인 보청기와 유사하지만 저주파수에서의 인공중이를 통한 이득이 일반적 인 보청기에 비교하여 작은 경향을 보여, 양측 감각신경성 난 청 환자에서는 반대쪽에 일반적인 보청기를 사용하여 저주 파수에서의 상대적으로 낮은 이득을 극복할 필요가 있다는 보고가 있다. ${ }^{17,18)}$ 따라서, 감각신경성 난청 환자들이 인공중이 를 선택함에 있어 이러한 주파수에 따른 변화 요소들에 대해 서도 고려해 보아야 하겠다.

본 연구의 전음성 난청 환자군에서 청각재활을 하지 않은 상태(unaided)에서의 기도 청력역치(77.1 dB HL)는 감각신경 성난청 환자의 청각재활을 하지 않은 상태(unaided)에서의 기 도 청력역치(60.1 dB HL)에 비교하여 유의하게 청력역치가 높았음에도 불구하고, 인공중이를 통해 보다 많은 기능적 이 득의 변화를 보였다. 이는 직접 와우를 자극하는 인공중이와 외부에서 소리를 증폭하여 기도골도차를 극복하여 와우를 자극해야 하는 일반적인 보청기와의 차이를 고려하면 인공중 이의 큰 장점으로 생각된다. 비록 국내에서는 건강보험 기준 으로 인하여 전음성 혹은 혼합성 난청 환자들에게 인공중이 를 시행하는 것이 보편적인 것은 아니나, 이미 많은 국외 연구 들에 의해 이들 환자들을 대상으로 인공중이를 시행하였을 때 상당한 임상적 효과를 기대할 수 있음이 보고된다. Gun$\mathrm{duz}$ 등 $^{19)}$ 과 Marino 등ㄱㅇㅢ 연구에 의하면 전음성 혹은 감각 
신경성 난청 환자들을 대상으로 기존의 보청기와 인공중이를 시행하였을 경우, 단어인지도(WRS)에는 큰 차이는 없었으나, 중음역대와 고음역대에서 인공중이를 시행하였을 경우 청력 개선에 더욱 효과적임을 보고하였다. ${ }^{6.7)}$ 체계적 고찰(systemic review)을 통해서도 중이 내 병변이 있는 환자들을 대상으로 기존 이소골대치술로 청력 개선이 되지 않는 환자들에 있어 서, 인공중이는 청력 개선에 있어서 효과적인 대안이 될 수 있다고 보고된다. ${ }^{8)}$ Busch 등 ${ }^{13)}$ 의 연구에 따르면, FMT coupling 방법(incus vibroplasty, RW vibroplasty with coupler, RW vibroplasty without coupler, OW vibroplasty with coupler)에 따라서 경도 및 중등도 난청 환자에서는 종류와 무 관하게 효과가 있는 것으로 보였으며, 골도청력이 $48 \mathrm{~dB} \mathrm{HL}$ 보다 큰 경우에는 RW vibroplasty with coupler의 소리 증폭 기능이 가장 효과적인 것으로 보고된다. 하지만 소아 및 청소 년에서 중이 내 질환 환자를 대상으로 시행한 인공중이에서, FMT의 위치가 최종적으로 청력 차이에 영향을 주지 않는다 는 보고도 있다.) 이외에 전음성 난청 환자에서 사용할 수 있는 청력재활 수술인 골도 이식형 보청기(bone anchoring hearing aid)와 인공중이의 청력 개선 효과를 비교한 연구에 의하면, 인공중이에서 더 높은 청력 개선 효과를 확인할 수 있었다. ${ }^{20)}$ 본 연구에서도 인공중이는 전음성 난청 환자에서 일반적인 보청기와 비교하여 이득의 차이나 언어인지도의 호 전 정도의 차이를 보였으나, 보청기와의 통계학적인 차이는 보이지 않았으며 향후 보다 많은 환자를 대상으로 분석이 필 요할 것으로 생각된다. 그러나, 본 연구에서 전음성 난청 환자 중 기존의 중이염 수술에 의한 외이의 변형에 따라 피드백의 발생이나 이통 및 잦은 이루의 발생으로 인해 보청기를 사용 하기 어려웠던 환자에서 인공중이를 통해 성공적인 청력 개 선을 얻을 수 있었으며, 이러한 보청기를 사용하기 힘든 전음 성 난청 환자가 인공중이를 통하여 효과적인 청각재활이 이 루어질 수 있음을 알 수 있어 전음성 난청에서 인공와우의 효용성을 명확하게 알 수 있다.

이 연구에는 몇 가지 제한점이 있다. 첫째, 현재 인공중이의 보험기준이 감각신경성 난청 환자 중 일정 청력 범위 안에서 보청기가 효과가 적은 환자로 제한하는 청각적 관점에만 집 중되고, 전음성 난청 환자들의 적용에 제한이 있어 환자군이 적은 점이다. 비록 이번 연구에서는 포함된 대상자 수가 적었 지만 감각신경성 난청 및 전음성 난청 환자의 인공중이를 통 한 청력 개선이 확인되었으며, 추후 더 많은 대상자를 대상 으로 연구를 시행한다면 보다 자세한 분석이 가능할 것으로 생각된다. 둘째, 이 연구의 평균 추적 관찰 기간이 약 18 개월 로 짧아 수술 후 인공중이로 인한 특별한 합병증은 보고되지 않았으나, 장기간 추적 관찰하였을 때 이 연구에서는 관찰되
지 못하였던 문제점들이 발생할 가능성도 배제할 수 없다. 현재까지 보고된 인공중이 수술 후 결과를 장기간 관찰한 연구에 의하면, 수술 후 골도 청력역치의 의미있는 악화는 관찰되지 않았으며, 장기적으로 기능적 이득이나 언어분별력 이 유지됨이 보고된다. ${ }^{21,22)}$ 드물게, 인공중이의 전선(wire)이 높은 비율로 노출되거나, ${ }^{23)}$ 침골 장각에 $\mathrm{FMT}$ 를 고정한 경우 침골장각의 소실이 보고되며, 미각 소실이 수술 후 2 6\%, 기 기 고장이 7 9\%로 보고된다. ${ }^{1,24}$ 이전 중이질환으로 인하여 공동개방 유양돌기삭개술(open cavity mastoidectomy)를 환자를 대상으로 시행한 연구를 보면, 인공중이는 전음성 난 청 환자들에 있어 청력 회복에 효과적인 방법이 될 수 있으 나, 인공중이의 전선(wire)이 높은 비율로 노출되는 현상이 보고되고 있어, 이에 대하여 중이강을 폐쇄하는 것이 필요함 이 보고되었다. ${ }^{23)}$ 따라서 부작용 등의 확인을 위해서는 많은 대상자 군이 포함된 장기간 추적 관찰을 포함하는 추가 연구 가 필요할 것으로 보인다.

본 연구를 통하여 인공중이는 감각신경성 난청 환자 및 전 음성 난청 환자에서 성공적인 청력 개선을 얻을 수 있는 방법 으로 확인되었다. 또한, 기존의 수술에 의한 외이도의 변형으 로 인한 문제로 기존의 보청기를 사용하지 못하는 환자와 잦 은 이루와 이통 등 외이도염을 않는 환자의 경우 인공중이는 좋은 치료적 선택이 될 수 있음을 확인할 수 있었다. 따라서, 감각신경성 난청 환자만을 위한 현재의 인공중이 건강보험 기준의 변화가 필요할 것으로 생각되며, 일반적인 보청기의 사용에 제약이 있는 전음성 난청 환자까지 확대 시행하여 인 공중이를 통해 얻을 수 있는 청력 개선 효과를 극대화하는 방안이 필요하겠다.

\section{Acknowledgments}

None.

\section{Author Contribution}

Conceptualization: Hong Ju Park. Data curation: Yeonjoo Choi. Formal analysis: Yehree Kim. Investigation: Taeuk Cheon. Methodology: Hong Ju Park. Project administration: Yeonjoo Choi. Resources: Yehree Kim. Software: Taeuk Cheon. Supervision: Hong Ju Park. Validation: Hong Ju Park. Visualization: Yeonjoo Choi. Writing — original draft: Yeonjoo Choi. Writing — review \& editing: Hong Ju Park.

\section{ORCIDs}

Hong Ju Park https://orcid.org/0000-0002-6331-8556

Yeonjoo Cho https://orcid.org/0000-0002-6990-2454

\section{REFERENCES}

1) Maw J. The Vibrant Soundbridge: A global overview. Otolaryngol Clin North Am 2019;52(2):285-95.

2) Korea Insurance Review Association. Medical care benefit of 
middle ear implant (2017). [cited 2020 Jun 1]. Available from: URL: http://www.hicra.or.kr/sub_asp/04_data01.html?mode=read\&read_ no $=1312 \&$ now page $=4 \&$ menu $=$.

3) Labassi S, Beliaeff M, Péan V, Van de Heyning P. The Vibrant Soundbridge ${ }^{\circledR}$ middle ear implant: A historical overview. Cochlear Implants Int 2017;18(6):314-23.

4) Pegan A, Ries M, Ajduk J, Bedeković V, Ivkić M, Trotić R. Active middle ear Vibrant Soundbridge sound implant. Acta Clin Croat 2019;58(2):348-53.

5) Butler CL, Thavaneswaran P, Lee IH. Efficacy of the active middleear implant in patients with sensorineural hearing loss. J Laryngol Otol 2013;127 Suppl 2:S8-16.

6) Clarós P, Pujol Mdel C. Active middle ear implants: Vibroplasty ${ }^{\mathrm{TM}}$ in children and adolescents with acquired or congenital middle ear disorders. Acta Otolaryngol 2013;133(6):612-9.

7) Marino R, Linton N, Eikelboom RH, Statham E, Rajan GP. A comparative study of hearing aids and round window application of the vibrant sound bridge (VSB) for patients with mixed or conductive hearing loss. Int J Audiol 2013;52(4):209-18.

8) Ernst A, Todt I, Wagner J. Safety and effectiveness of the Vibrant Soundbridge in treating conductive and mixed hearing loss: A systematic review. Laryngoscope 2016;126(6):1451-7.

9) Verhaegen VJ, Mylanus EA, Cremers CW, Snik AF. Audiological application criteria for implantable hearing aid devices: A clinical experience at the Nijmegen ORL clinic. Laryngoscope 2008; 118(9):1645-9.

10) Luetje CM, Brackman D, Balkany TJ, Maw J, Baker RS, Kelsall D, et al. Phase III clinical trial results with the Vibrant Soundbridge implantable middle ear hearing device: A prospective controlled multicenter study. Otolaryngol Head Neck Surg 2002;126(2):97107.

11) Ihler F, Bewarder J, Blum J, Matthias C, Canis M. Long-term functional outcome and satisfaction of patients with an active middle ear implant for sensorineural hearing loss compared to a matched population with conventional hearing aids. Eur Arch Otorhinolaryngol 2014;271(12):3161-9.

12) Lee HJ, Lee JM, Choi JY, Jung J. Evaluation of maximal speech intelligibility with Vibrant Soundbridge in patients with sensorineural hearing loss. Otol Neurotol 2017;38(9):1246-50.

13) Busch S, Lenarz T, Maier H. Comparison of alternative coupling methods of the Vibrant Soundbridge floating mass transducer. Audiol Neurootol 2016;21(6):347-55.

14) Zwartenkot JW, Snik AF, Mylanus EA, Mulder JJ. Amplification options for patients with mixed hearing loss. Otol Neurotol 2014; 35(2):221-6

15) Wagner F, Todt I, Wagner J, Ernst A. Indications and candidacy for active middle ear implants. Adv Otorhinolaryngol 2010;69:20-6.

16) Snik AF, Cremers CW. Vibrant semi-implantable hearing device with digital sound processing: Effective gain and speech perception. Arch Otolaryngol Head Neck Surg 2001;127(12):1433-7.

17) Mlynski R, Dalhoff E, Heyd A, Wildenstein D, Rak K, Radeloff A, et al. Standardized active middle-ear implant coupling to the short incus process. Otol Neurotol 2015;36(8):1390-8.

18) Jung J, Roh KJ, Moon IS, Kim SH, Hwang KR, Lee JM, et al. Audiologic limitations of Vibrant Soundbridge device: Is the contralateral hearing aid fitting indispensable? Laryngoscope 2016;126(9):2116-23.

19) Gunduz B, Atas A, Bayazit YA, Goksu N, Gokdogan C, Tutar H. Functional outcomes of Vibrant Soundbridge applied on the middle ear windows in comparison with conventional hearing aids. Acta Otolaryngol 2012;132(12):1306-10.

20) Mojallal H, Schwab B, Hinze AL, Giere T, Lenarz T. Retrospective audiological analysis of bone conduction versus round window vibratory stimulation in patients with mixed hearing loss. Int $\mathrm{J}$ Audiol 2015;54(6):391-400.

21) Labassi S, Beliaeff M. Retrospective of 1000 patients implanted with a Vibrant Soundbridge middle-ear implant. Cochlear Implants Int 2005;6 Suppl 1:74-7.

22) Vincent C, Fraysse B, Lavieille JP, Truy E, Sterkers O, Vaneecloo FM. A longitudinal study on postoperative hearing thresholds with the Vibrant Soundbridge device. Eur Arch Otorhinolaryngol 2004;261(9):493-6.

23) Lassaletta L, Calvino M, Sánchez-Cuadrado I, Pérez-Mora RM, Muñoz E, Gavilán J. Pros and cons of round window vibroplasty in open cavities: Audiological, surgical, and quality of life outcomes. Otol Neurotol 2015;36(6):944-52.

24) Zwartenkot JW, Mulder JJ, Snik AF, Cremers CW, Mylanus EA. Active middle ear implantation: Long-term medical and technical follow-up, implant survival, and complications. Otol Neurotol 2016;37(5):513-9. 